Geologische Rundschau 75/1 |97-104| Stuttgart 1986

\title{
Sedimentation processes on the antarctic continental margin at Kapp Norvegia during the Late Pleistocene
}

By HANNES GROBE, Bremerhaven*)

With 7 figures

\section{Zusammenfassung}

An vier Sedimentkernen eines Frofils am antarktischen Kontinentalhang vor Kapp Norvegia wurden Eisfracht, biogene Komponenten, Korngrößenverteilungen und Tonmineralvergesellschaftungen bestimmt. Die Verteilung der sedimentologischen Parameter zeigt eine zyklische $\mathrm{Ab}$ folge von drei verschiedenen Sedimentfazies, die die klimatisch gesteuerten Veränderungen innerhalb der Hydrossphäre und der Kryossphäre widerspiegeln.

Die drei Sedimentfazies werden warmen und kalten Klimaperioden sowie einer kurzen Úbergangszeit zugeordnet. Der für polare Sedimente ungewöhnlich hohe Gehalt an kalkigen benthonischen und planktonischen Foraminiferen sowie die Verzahnung vorwiegend terrigener mit biogenreichen Sedimenten bei zunehmender Entfernung vom Kontinent lassen den Einfluß der Weddell See-Polynya und die Oszillationen von Schelfeiskante und Packeisbildung während des späten Pleistozäns erkennen.

\section{Abstract}

Sedimentological analyses concerning ice rafted debris, grain size distribution, biogenous components, and clay mineral composition of four sediment cores from the Antarctic continental margin off Kapp Norvegia reveal a cyclical pattern of three different sediment facies. These are classified into warm and cold types representing warm and cold a climatic periods and short transition period from cold to warm events.

The sedimentological parameters reflect the variations within the cryosphere and the hydrosphere, which are directly influenced by the climatic fluctuations. The unusually high content of carbonaceous planktonic and benthonic foraminifera in these polar sediments, as well as the interfingering of terrigeneous and biogeneous-rich sediments with increasing distance from the continent, might reflect the influence of the Weddell Sea Polynya and the oscillations of polynya, packice and ice shelf extent during the late Pleistocene.

\section{Résumé}

Des analyses sédimentologiques ont été effectuées sur 4 carottes prélevées le long d'un profil dans les sédiments de la

\footnotetext{
*) Author's' address: H. GROBE, Alfred-Wegener-Institut für Polarforschung, 2850 Bremerhaven.
}

marge continentale antarctique au large du cap Norvegia. Elles ont porté sur les débris amenés par les glaces, la granulométrie, les composants biogéniques et la composition des constituants argileux. Ces analyses révélent une succession cyclique de 3 facies sédimentaires; ceux-ci correspondent à des périodes climatiques chaudes et froides, ainsi qu’à de courtes périodes de transition du froid vers le chaud.

Les paramètres sédimentologiques reflètent des variations de l'hydrosphère et de la cryosphère, directement influencées par les fluctuations climatiques. La teneur anormalement élevée de ces sédiments polaires en foraminifères carbonatés planctoniques et benthoniques, ainsi que lindentation de sédiments terrigènes et de sédiments riches en éléments biogéniques, peuvent traduire l'influence de la polynie de la Mer de Weddell, ainsi que les oscillations des surfaces occupées par la polynie, le pack et l'iceshelf, au cours du Pleistocène tardif.

\section{Краткое содержание}

Был исследован материал из четырех кернов буровых скважин антарктического континентального склона в районе мыса Норвегии. В этом материале определили биогенные компоненты, а также гранулометрический и глинистоминералогический состав. Распределение седиментологических параметров указывает на циклические смены трех различных осадочных фаций, отображающих изменения в гидросфере и криосфере, и связанных с климаTOM.

Высокое содержание известковых фораминифер бентосы и планктона, столь необычное для полярных осадочных пород, как и смешание преимущественно терригенных седиментов с таковыми, богатыми биогенным материалом при возрастающем отдалении от матери, разрешают установить влияние Weddell See-Polynya и колебания при образовании полыней, плавучего и шельфового льда во время позднего плейстоцена.

\section{Introduction}

Ice and snow cover a significant portion of the earth's surface and thus strongly influence global climate. The Antarctic ice, pack ice as well as the 
large ice shield, is an important factor here. The sediments around the Antarctic continent will tell us something about the role and behavior of the cryosphere and the hydrosphere and their interrelationship with climate during the past ice ages, which is important for the understanding of the palacoclimatic variations during recent geological times.

Hitherto very little work has been done on this subject. ANDERSON (1972) originally proposed a model for the reconstruction of ancient glacial-marine environments as determined from different foraminiferal assemblages in the Weddell Sea. The Southern Ocean marine sedimentation model of WEAVER (1973) puts more emphasis on ice and current derived sediments but only deals with Pliocene sediments, as does Chapius (1974). Fillon (1977) reconstructed paleotemperatures in the Ross Sea by using ice rafted debris sedimentation rates and WATKINS et al. (1982) worked out a model of IRD accumulation during alternating climatic cycles at different latitudes of the Southern Ocean. Also radiolaria (CoOke \& HaYs, 1982) and silicoflagellates (CIESIELSKI, 1974) were used to reconstruct climatic conditions in Antarctica.

This paper's goal is to submit the first results of sedimentological analyses of sediment cores taken on a profile at the Antarctic continental margin in the Weddell Sea close to the edge of the ice shelf. The results are interpreted with respect to palaeoclimatic variations in Antarctica during the late Pleistocene.

\section{Methods}

Four sediment cores were taken on the first cruise of RV Polarstern during the southern summer $1983 / 84$, on a profile off Kapp Norvegia located at the northeastern coast of the Weddell Sea (Fig. 1). The morphology shows a shelf at a depth of about $250 \mathrm{~m}$ with grooves made by icebergs (plough marks; LIEN 1981) followed by a steep slope to a depth of $1800 \mathrm{~m}$. Between this slope and another one between 3000 and $4600 \mathrm{~m}$, we find a flat terrace which, in this location, is about $100 \mathrm{~km}$ wide (Fig. 2). On this profile preliminary seismic investigations by multichannel reflection seismic have been done by Hinz \& Krause (1982). To obtain information about the uppermost sediment layers, the profile was presurveyed with a $3.5 \mathrm{kHz}$ echograph. Core locations were selected, where the seismic profile showed several reflectors down to a depth of about $100 \mathrm{~m}$, because in these locations a good core recovery was to be expected (Fig. 2). The sediment cores were analysed for the content of ice rafted debris (IRD), and biogenous components, grain size distribution and clay mineralogy.

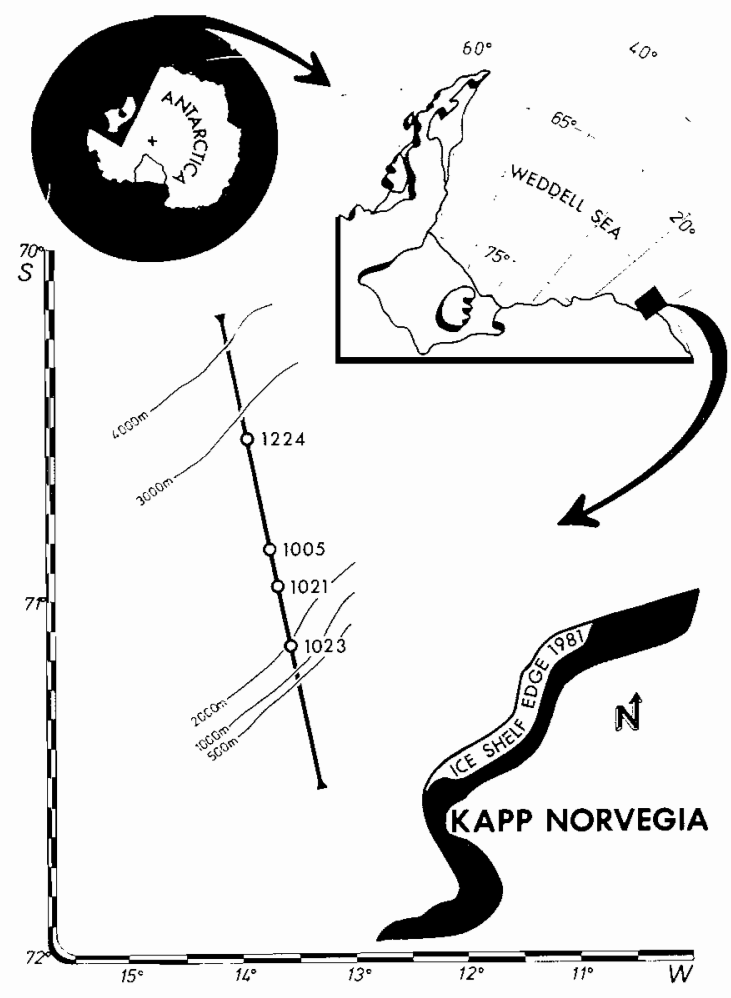

Fig. 1. Location of the sediment cores on the profile at the northeastern continental margin of the Weddell Sea.

To obtain information about the distribution of IRD within the sediment column, a new method was used. In the X-radiographs the amount of gravel larger than $2 \mathrm{~mm}$ was counted in one centimenter horizons down core and plotted against depth with length of lines corresponding to the number of grains (Grobe 1985). The X-radiographs also were used for the determination of bedding characteristics.

The computation of the grain size parameters of the cumulative curves after FOLK (1966) is not possible because these glaciomarine sediments contain more than $25 \%$ clay. In this particular case the $25 \%$-point of the cumulative curve was used to obtein information about the sediment's relative mean grain size.

The content of biogenous and terrigenous components in the sand fraction was determined by coarse fraction analyses (SARNTHEIN 1972). The data have been multiplied with the percentage of sand to obtain values related to the bulk sample.

Clay mineral composition was analysed by $\mathrm{X}$-ray diffraction and evaluated using the methods by LANGE (1982) and STEIN (1984). Montmorillonite is 


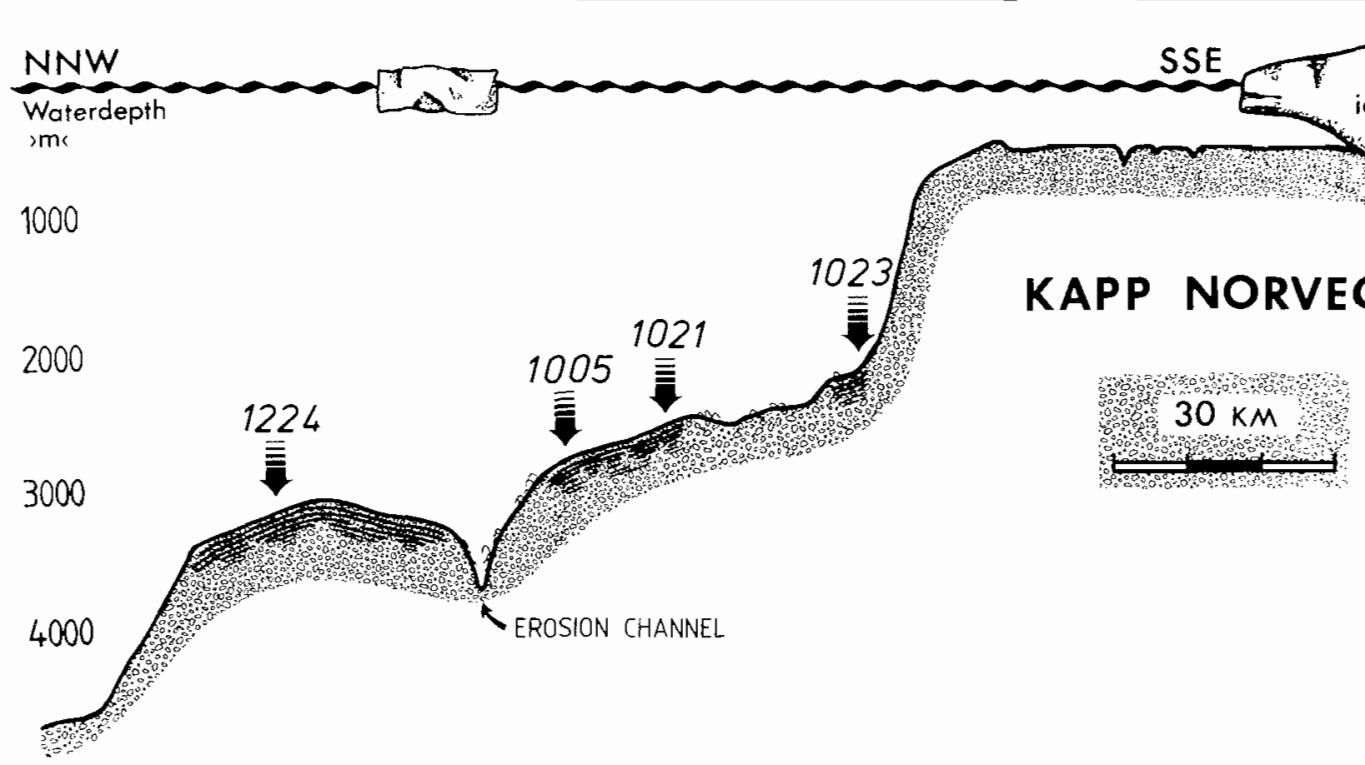

Fig. 2. Morphology of the profile off Kapp Norwegia. Grooves on the shelf are made by icebergs (plough marks; LIEN 1981). The lower part of the slope terrace is separated by a small erosion channel. Core locations were selected where the 3.5 $\mathrm{kHz}$ seismic survey showed several reflectors.

plotted as the percentage of the three observed clay minerals clorite, illite and montmorillonite because it shows the strongest variations. Kaolinite is absent, as it is a product of chemical weathering processes which do not occur on Antarctica and the source region for these sediments are primarily the cristalline rocks of East Antarctica.

Sedimentation rates in core 1021 were determined by 230-Thorium- (MANGini 1984, unpubl. data) and in the uppermost part of core 1224 by 14-Carbon-isotopes.

\section{Results}

The sediments near Kapp Norvegia contain several horizons rich in biogenous components, although most of them have been altered by diagenetic processes. The high amount of arenaceous foraminifera in the sediment surface samples already decreases sharply down to nearly zero percent in the uppermost centimeters of the cores. As for biogenous opal, diatoms have been found only in the surface layers of the cores, whilst radiolaria and sponge spicules also decrease with depth, but can still be found at the bottom of some cores at a depth of about six meters. Carbonaceous foraminifera tests are only affected by dissolution in core 1224, at the deepest part of the profile, because of the influence of the lysocline. The carbonate content of up to $25 \%$, which is unusually high for polar sediments, is mainly composed of the left coiling planktonic foraminifera, Neogloboquadrina pachyderma (sinistral). There is a good correlation between the occurence of this planktonic foraminifera and several species of benthonic carbonaceous foraminifera.

A detailed description of core 1021 will give an indication of the sediment character (Fig. 3). The sediment exhibits cyclical colour fluctuations, which the sedimentological analysis proved to be fluctuations in sediment type. The IRD content reveals cyclical variations, which correlate well with the grain size distribution. Coarse sediment contains, in most cases, a large amount of planktonic foraminifera and very often there is a radiolarian peak at the base of a foraminiferal peak. If the mean grain size is fine and the clay content is high, the amount of montmorillonite is also high. As the $\mathrm{X}$-radiographs show, the sediment is generally heavily bioturbated, but if it is very rich in clay, it tends to be laminated. The distribution of the sedimentological parameters shows a good correlation between high IRD content, coarse mean grain size, high carbonate content and low content of montmorillonite. The present investigations show that three characteristic sediment facies can be differentiated, here termed as the $»$ warm, cold and transition types (Fig. 4).

Type cold is a fine sediment with high clay content, consisting mainly of montmorillonite with little 


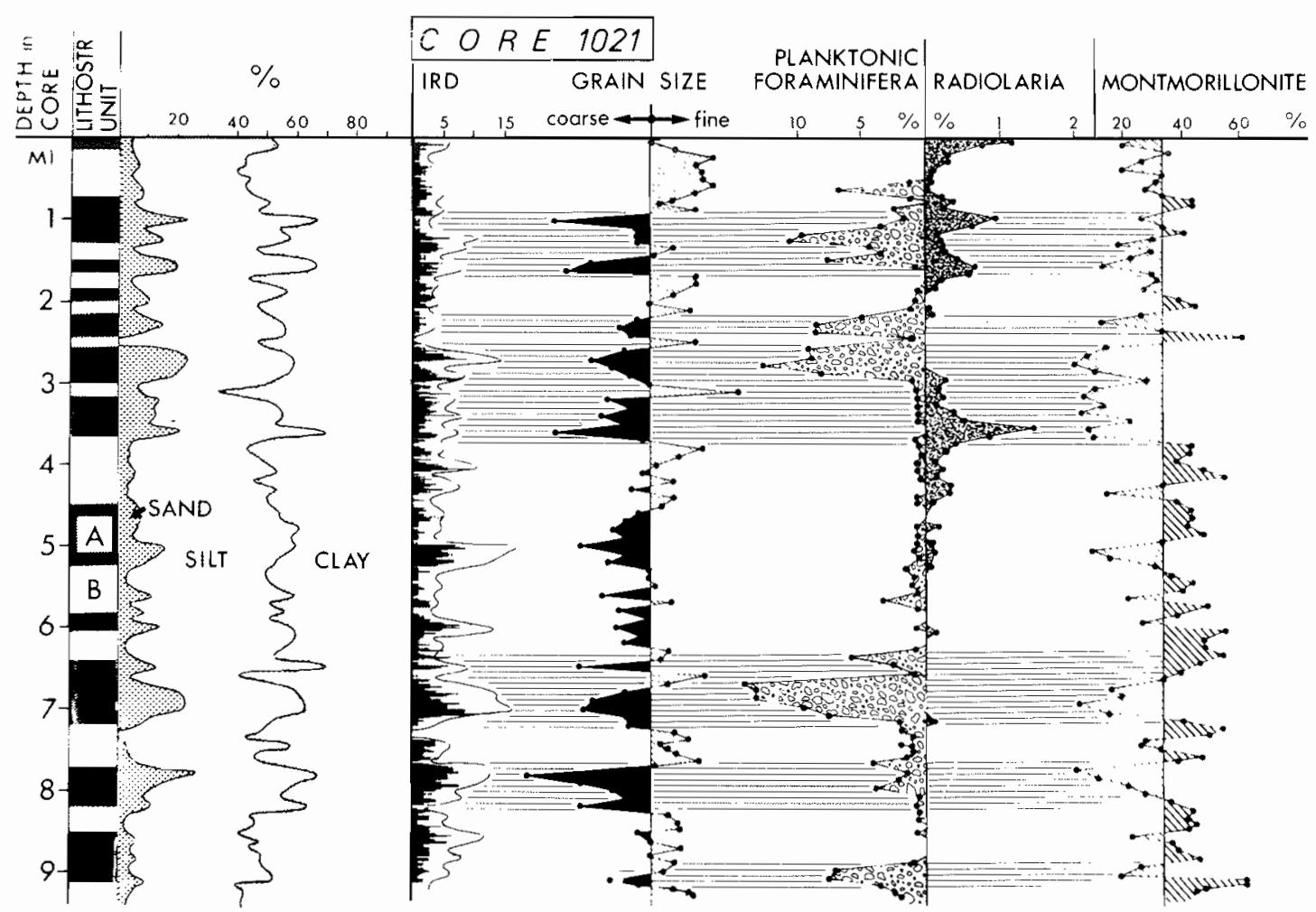

Fig. 3. Distribution of sedimentological parameters of core 1021. Lithostratigraphic unit A has a greyish, unit B a brownish colour. The cyclical pattern of two different units is also found in the distribution of ice rafted debris (IRD), grain size, and the percentage of foraminifera and montmorillonite. There is a good relationship between high IRD, coarse grain size, high content of foraminifera and low content of montmorillonite. Radiolarian peaks are mostly at the base of a foraminiferal peak.
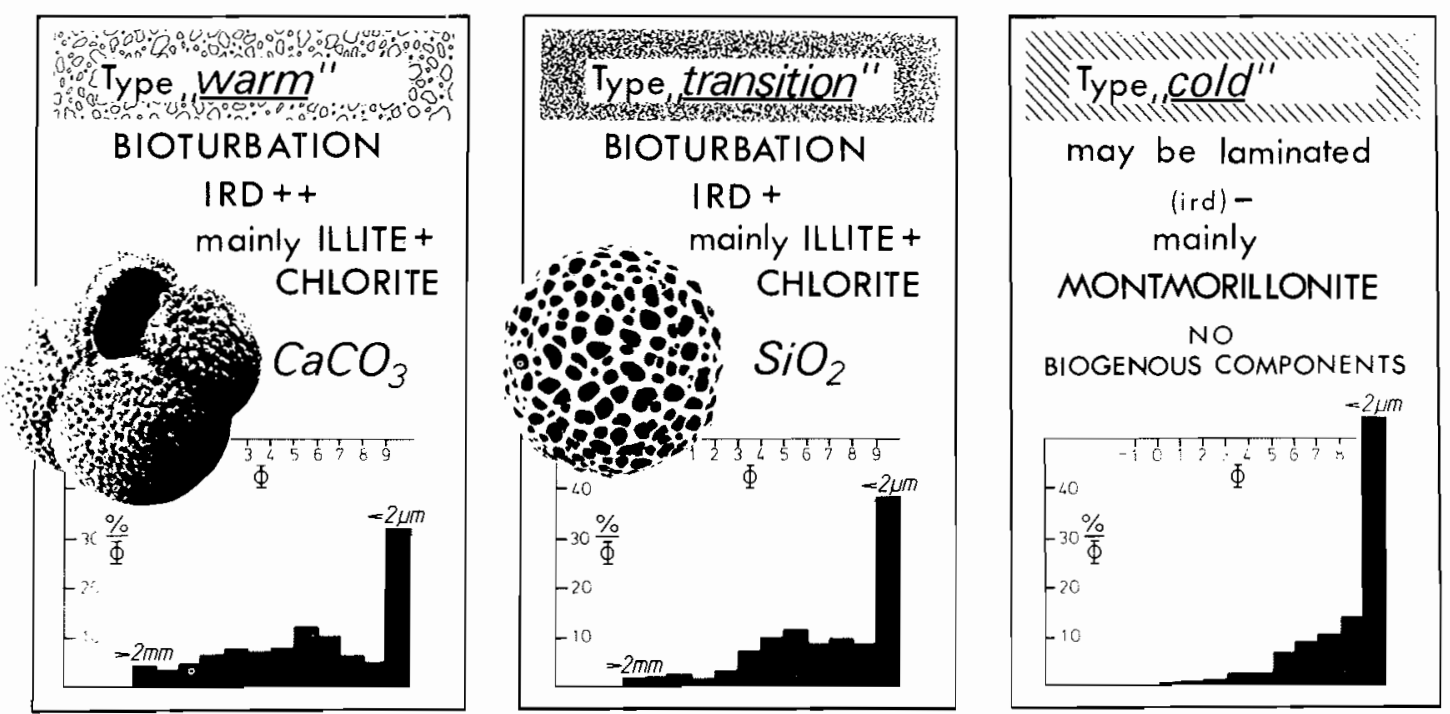

Fig. 4. Three sediment facies can be distinguished. Type warm and type cold are very different and are supposed to be deposited during warm and cold climatic periods. Type transition is a sediment which is very similar to type warm and appears only as a short event during the transition from cold to warm. The histograms show the typical grain size distributions. 
or no biogenous components. IRD is low or absent if the sediment is laminated. In contrast to this, the sediment type warm has a coarse mean grain size and a high content of IRD. The clay minerals are mainly chlorite and illite and the bioturbated sediment contains up to $25 \%$ carbonate exclusively consisting of foraminifera. Very similar to type warm in most parameters is the type transition. Grain size can be intermediate but the main difference is a high content of radiolaria instead of foraminifera. Type transition is only found at the base of type warm. Sedimentation rates at both ends of the profile are about 2 $\mathrm{cm} / 1000 \mathrm{y}$, and are twice as high as the middle (1.1 $\mathrm{cm} / 1000 \mathrm{y})$. An increasing interfingering of biogeneous sediments with terrigeneous sediments from south to north can be found.

\section{Discussion}

The sediment characteristics described above suggest, that the different types of sediment are formed by four main sedimentation processes. The production of plankton and benthos is responsible for the content of biogeneous components, whilst terrigeneous material is transported by currents, icebergs and downslope movement. The primary sediment composition may be modified by diagenetical alterations such as the solution of the biogenic particles and formation of authigenic minerals eg. glauconite and manganese-micronodules.

Sediment transport and biogeneous productivity are controlled by three processes, in turn controlled by the cryosphere and hydrosphere, which are directly linked to climatic variations. These are, first the fluctuations of the ice shelf edge, second the formation of pack ice, and third the varations in the extent of the Weddell Sea Polynya.

The polynya, observed since 1973 by satellite (CARSEY 1980) and on particular expeditions (GorDON 1982), is an ice-free enclosure in the pack ice, situated in the eastern part of the Weddell Sea during winter time. This polynya does not form every year, but when it does, it is always found in approximately the same position in the vicinity of Kapp Norvegia (ZWALLY et al. 1983).

The only limiting factor for the productivity of plankton in the nutrient rich Antarctic waters is the lack of sun light. There is no sun light under the pack ice, therefore productivity starts in spring when the pack ice is melting. SAKSHAUG (1984) mentions that there is a delay of the spring bloom with increasing latitude due to light and ice effects. If there is a polynya instead of pack ice, the plankton bloom can start earlier, is higher and lasts for a longer time. This could be the reason for the high content of biogeneous components at the seaward end of the profile. ANDERSON (1972) suggested that the high amount of microfossils at the east coast of the Weddell Sea is due to upwelling. This upwelling may also be the cause of the polynya.

The genesis of the type warm and type cold sediment are supposed to be formed during warm and cold periods by the interplay of different hydrographic and ice conditions. High sedimentation rates at the northern end of the profile are due to a high productivity of plankton and benthos under the influence of the Weddell Sea Polynya during warm conditions (Fig. 5). The biogeneous input decreases towards the southern end of the profile, where we find, in contrast, the high sedimentation rates being caused by the high input of terrigeneous material from the continent. The lowest sedimentation rates of both processes can be found in the middle of the profile.

During cold periods (Fig. 6) biogeneous productivity is reduced to nearly zero because of the large extent of pack ice and ice shelf and the probable absence of the polynya. Mostly at the beginning of a cold period, the input of IRD is low. The ice shelves are grounded because of a lower sea level, therefore calving of icebergs is strongly reduced. The edge of the ice shelf extends beyond the continental slope (HoLLIN 1962). Under the ice shelf mostly current derived sediment will be deposited. This drastic change in the main sediment supply process, from ice rafted to current derived sediments, is probably the reason for the change observed in the composition of clay minerals. Severe glacial conditions may result in very slow deposition of muds, devoid of IRD and planktonic microfossils beneath the ice cover (ANDERSON 1972). Sedimentation rates are low and more or less constant along the profile.

Of course every transition type between these two extreme stages is possible, but the transition from cold to warm especially is very often accompanied by the appearence of biogenous opal. The short event of the type »transition « sediments, rich in radiolaria, is only found at the base of the type »warm « (Fig. 7). It seems that at the beginning of warm period there is always a high productivity of siliceous organisms, displaced with a little time delay by a high productivity of carbonaceous plankton and benthos, which lasts throughout the whole warmer period. This interesting ecological problem might reflect changes of water masses, but is still not understood.

ANDERSON (1972) notes that the dry base conditions of the Ronne and Larsen ice shelf in recent times seem to suggest that the Weddell Sea is at the be- 


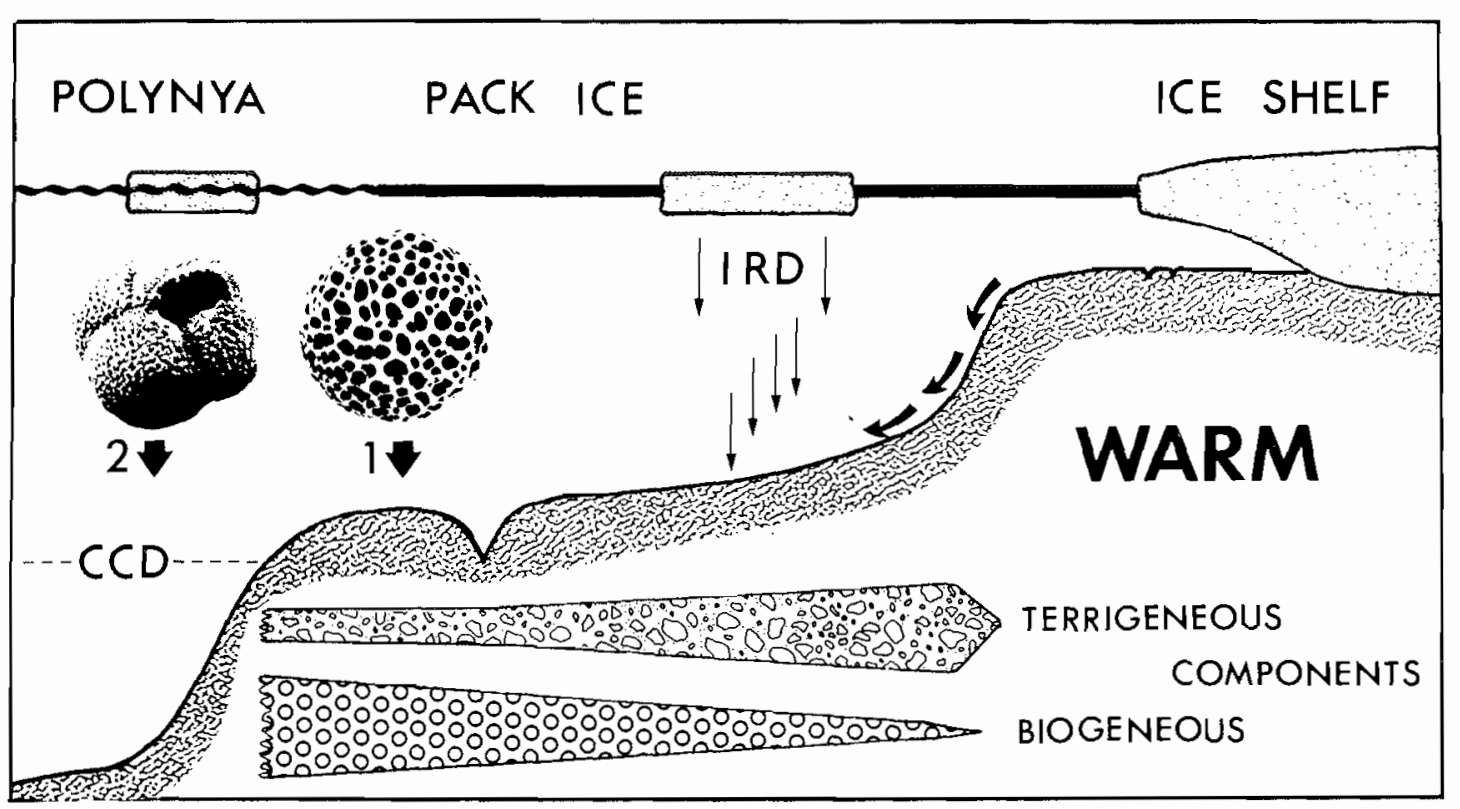

Fig. 5. During the deposition of a warm type sediment, there are high sedimentation rates at the northern end of the profile due to a high productivity of plankton and benthos. This process decreases towards the continent where, instead, high sedimentation rates are caused by a high input of terrigeneous material, which is mainly ice rafted and transported down the upper steep slope. The resultant sedimentation rate has its minimum in the middle of the terrace. The CCD is at about 3000 m.

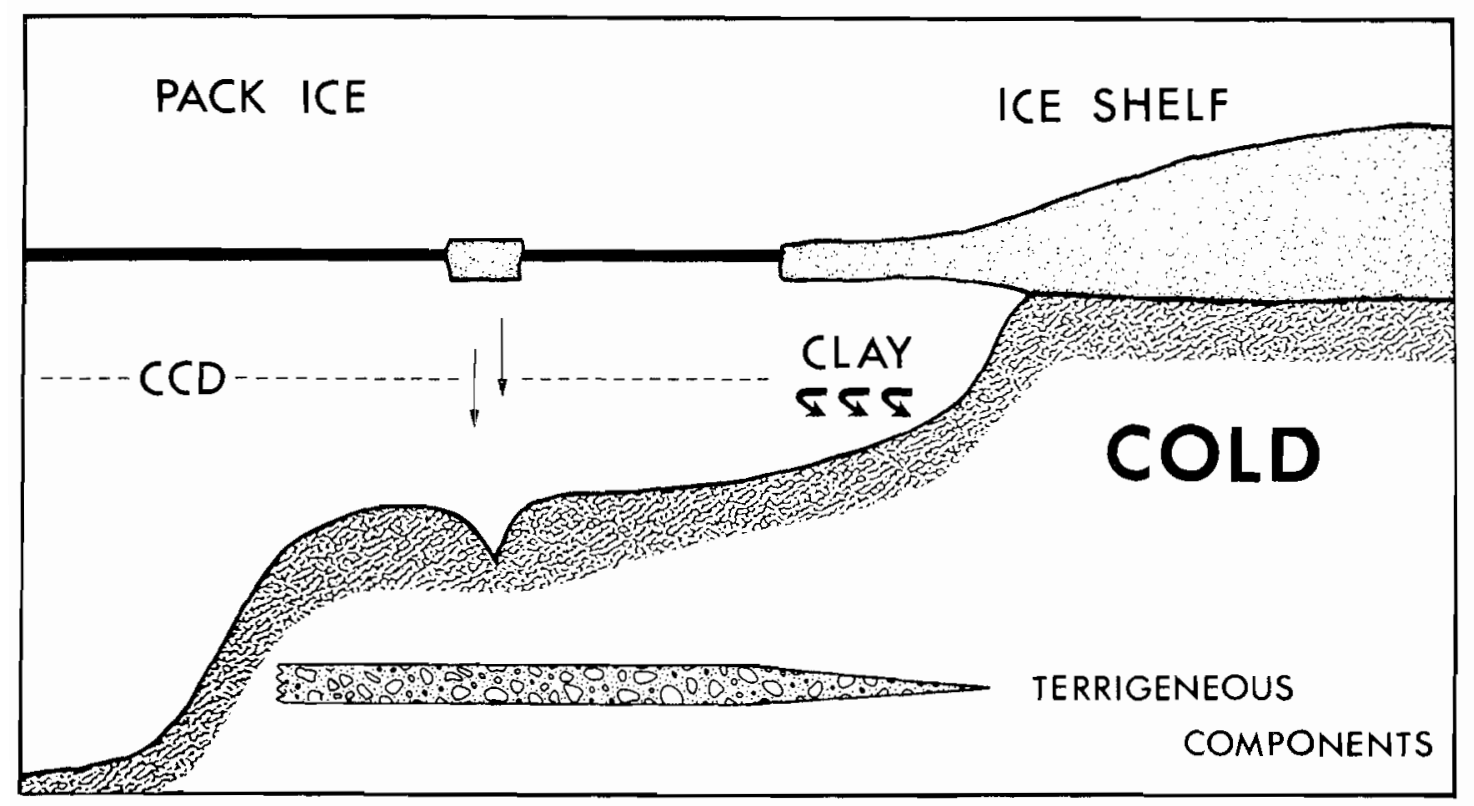

Fig. 6. Under cold climatic conditions the productivity of biogeneous material is strongly reduced. The edge of the ice shelf is further north beyond the continental slope, so that mostly current derived sediment will be deposited. Sedimentation rates are nearly constant along the profile and the CCD might be very shallow. 


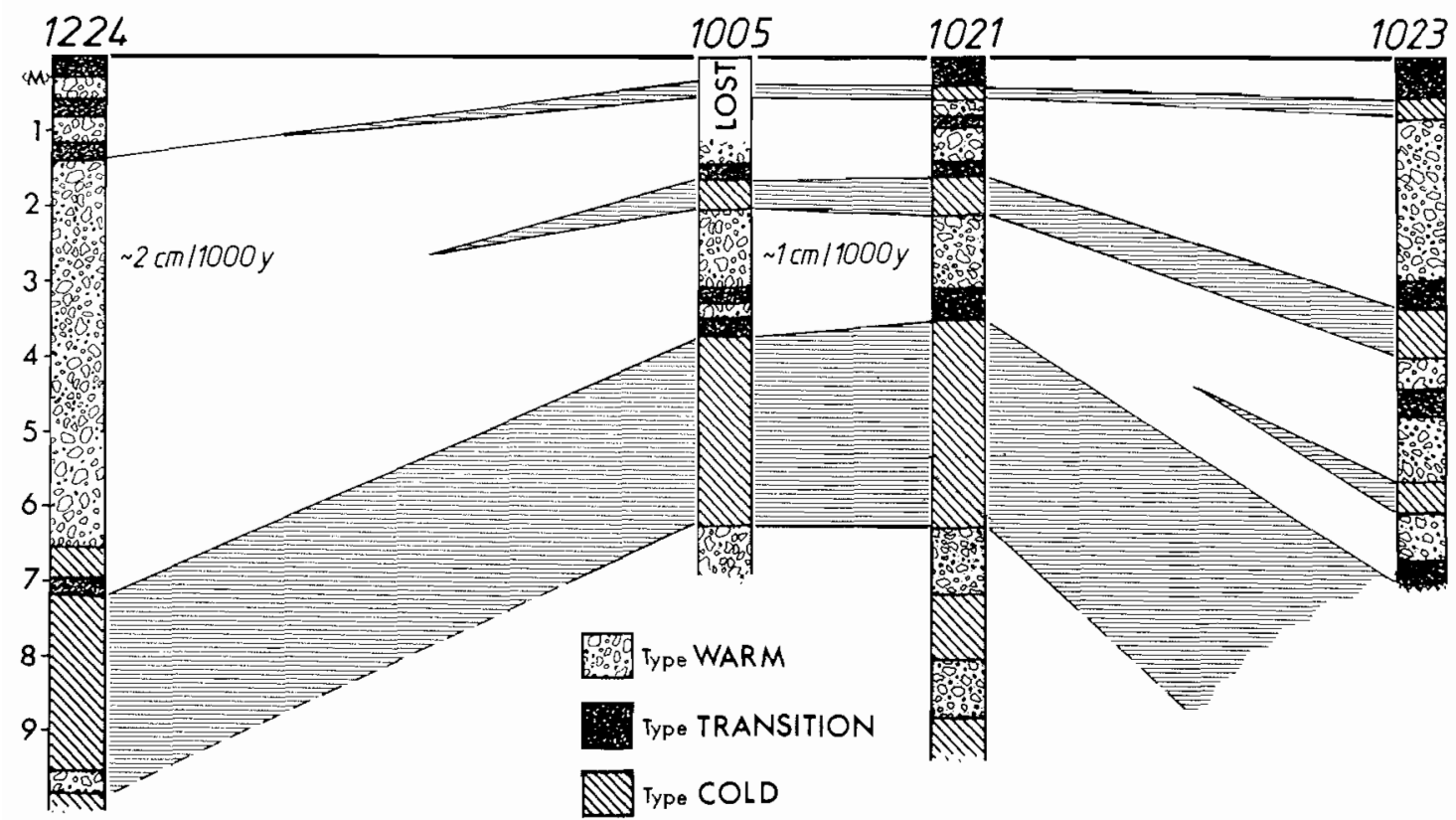

Fig. 7. Correlation of the cores with the three al ternating sediment facies works well with the observed sedimentation rates. The type transition appears only at the base of the type warm sediment and on top of the cores. The interfingering of the type cold and type warm sediment represents the fluctuations of polynya, ice shelf and pack ice extent in response to the climatic variations

ginning of a new glacial interval. But the high amount of opal in the uppermost parts of the cores shows that during subrecent times a transition type sediment has been deposited, indicating that this will be followed by a warm period, which is the recent interglacial.

The fragmentation index, which gives the percentage of broken foraminiferal tests, is low in cores shallower than $2000 \mathrm{~m}$ water depth. Only core 1224 shows an index of up to $70 \%$, especially in horizons with a low content of foraminifera. This seems to reflect the influence of an oscillating CCD which is shallower during cold periods. FrL.LON (1975) suggest that an increase in the concentration of dissolved carbon dioxide under an expanded ice shelf during cold periods is implied by a rise of the CCD. ConLiss \& Thunell (1983) also found that cool intervals show low carbonate values and increased foraminiferal fragmentation in cores from the Southeast Indian Ridge near the Polar Front. The CCD at present is at a depth of about $3000 \mathrm{~m}$ in this part of the Weddell Sea (ANDERSON 1972) which agrees with the findings presented here. The reason for the cyclic fluctuations in the carbonate content between 0 and $15 \%$ in the shallower cores must be a change of primary production, not solution beneath the CCD, because the deepest core 1224 contains carbonate throughout its upper 7 meters which cover the period of about 300,000 years.

During severe glacial conditions the CCD may have extended above the continental shelf because of increased Antarctic Bottom Water thickness (ANDERSON 1972). Such a rise of the CCD could have occured in the lower parts of the cores, where a broad horizon of the type cold sediment, older than $300,000 y$ and without any biogeneous component, is found at any depth on the continental slope.

The warm as well as the cold type sediment, as described here, represent the extreme stages of the facies and agree in parts with ANDERSON's (1972) observations of sedimentology and CCD-fluctuations. The warm type sediment in this work is similar to ANDERSON's wet base stage and the cold type sediment to his dry base stage. The correlation of all cores (Fig. 7) shows the changes within the three different sediment types along the profile. With decreasing distance from the continent more and more type »cold « sediments can be found, whilst the biogeneous content of the type "warm « sediments also decreases on the shallower part of the continental slope. The interfingering of the two main sediment facies is the result of the oscillation of pack ice, ice shelf and polynya extent in response to climatic variations. 


\section{Acknowledgements}

The author wishs to thank D. Fütterer, R. Gersonde (Bremerhaven) and J. Pätzold (Kiel) for supporting this paper with help and discussions and A. Mangini (Heidelberg) and W. Weber (Kiel) for age determinations. Special thanks also to the crew of RV POLARSTERN for their kind support in obtaining the sediment cores and to F. Westall (Bremerhaven) and B. Junge (Kiel) for reviewing the manuscript.

\section{References}

ANDERSON, J. B. (1972): The marine geology of the Weddell Sea, - Ph. D. Thesis, Florida State Univ., Contrib. No. 35, $222 \mathrm{~S}$.

CARSEY, F. D. (1980): Microwave observation of the Weddell polynya. - Mon. Wea. Rev., 108, 2032-2044

Chapius, R. A. (1974): Sediment response to climatic change as recorded in deep sea piston cores from the Southern Ocean. - Master Thesis, Florida State Univ. Contr. No. 38., 107 S.

COOKE, D. W. \& HAYS, J. D. (1982): Estimates of Antarctic ocean seasonal sea-ice cover during glacial intervals. - In: CRAdDock, C. (ed.): Antarctic Geoscience, Univ. Wisconsin Press, Madison.

Corliss, B. H. \& Thunell R. C. (1983): Carbonate sedimentation beneatl the Antarctic circumpolar current during the late Quatemary. - Mar. Geol., 51 (3-4), 293-326.

CIESIELSKI, P. F. (1974): Silicoflagellate paleotemperature curve for the Southern Ocean. - Antarctic J. U.S., 9 , 269-270.

Filion, R. H. (1975): Late Cenozoic paleo-oceanography of the Ross Sea, Antarctica.-Geol. Soc. Am. Bull., 86, 839-845.

- (1977): Ice-rafted detritus and paleotemperature: late Cenozoic relationship in the Ross Sea region. - Mar. Geol., 25, 73-93.

FoLK, R. L. (1866): A review of grain-size parameters. Scdiment., 6, 73-93.

GORDON, A. L. (1982): The U.S.-U.S.S.R. Weddell polynya expedition. - Antarctic J. U.S., 17(5), 96-98.

Grobe, H. (1985): A new method for the determination of ice rafted debris in sediment cores. - In preperation.

HiNZ, K. \& KRAUSE, W. (1982): The continental margin of Queen Maud Land/Antarctica: seismic sequences, structural elements, and geological development. Geol. Jb., E23, 17-41.

Hollin, J. T. (1962): On the glacial history of Antarctica. - J. Glac., 4, 173-195.

LANGE, H. (1982): Distribution of chlorite and kaolinite in eastern Atlantic sediments off North Africa. - Sedimentol., 29, 427-431.

LIFN, R. (1981): Sea bed features in the Blaaenga area, Weddell Sea, Antarctica. - Proc. 6th int. conf. on port and ocean eng. und, arctic cond., 706-716, Quebec, Canada.

SakshaUg, E. \& Holm-Hansen, O. (1984): Factors governing pelagic production in polar oceans. - In: Holm-Hansen, O.; Bolis, L. \& Gilles, R. (eds)., lecture notes on coastel and estuarine studies, vol. 8, Springer Verlag.

SARNTHEIN, M. (1971): Oberflächensedimente im Persischen Golf und Golf ron Oman. II. Qualitative Komponentenanalyse der Grobfraktion. - METEOR-Forschungserg. Reihe C, Nr. 5, $112 \mathrm{~S}$.

STEIN, R. (1984): Zur neogenen Klimaentwicklung in Nordwest-Afrika und Paläo-Ozeanographie im Nordost-Atlantik: Ergebnisse von DSDP-Sites 141, 366, 397 und 544B. - Rpts. Geol.-Derise Paläont. Inst. Univ. Kiel, Nr. 4., 210 S.

WEAVER, F. (1973): Pliocene paleoclimatic and paleoglacial history of east Antarctica recorded in deep-sea piston cores. - Sec. Res. Lab., Florida State Contrb. No. 36, $142 S$.

Zwaliy, H. J.; Comisco, J. C.; Parkinson, C. L. Campbell, W. J.; Carsey, F. D. \& Gloersen, P. (1983): Antarctic sea ice, 1973-1976: satellite passive microwave observation. - NASA, Sp-459, Washington DC, $206 \mathrm{~S}$ 